\title{
Deoxyribonucleotide Sequence Relationships Among Bordetella Species $\dagger$
}

\author{
WESLEY E. KLOOS, ${ }^{1}$ NIRUPAMA MOHAPATRA, ${ }^{1}$ WALTER J. DOBROGOSZ, ${ }^{2}$ JOHN W. EZZELL, ${ }^{2}$ \\ AND CHARLES R. MANCLARK ${ }^{3}$ \\ Departments of Genetics, ${ }^{1}$ and Microbiology, ${ }^{2}$ North Carolina State University, Raleigh, North Carolina \\ 27650, and Bureau of Biologics, Food and Drug Administration, Bethesda, Maryland $20205^{3}$
}

Deoxyribonucleotide sequence relationships among currently recognized Bordetella species (Bordetella pertussis, Bordetella parapertussis, and Bordetella bronchiseptica) were examined by deoxyribonucleic acid (DNA) hybridization involving the hydroxyapatite batch procedures of Brenner and co-workers. The results indicated that strains from all species tested were highly related. At the stringent criterion $\left(80^{\circ} \mathrm{C}\right)$, the relative binding of $B$. pertussis DNA to $B$. parapertussis DNA was $75 \pm 9 \%$, and to $B$. bronchiseptica DNA it was $73 \pm 8 \%$. Intraspecies binding was $93 \pm 8 \%$. Under similar conditions, the relative binding of $B$. parapertussis DNA to $B$. bronchiseptica DNA was $85 \pm 9 \%$. The various so-called Bordetella species may be reconsidered as representing different subspecies belonging to a single species.

The genus Bordetella is currently composed of three phenotypically distinguishable species: Bordetella pertussis, Bordetella parapertussis, and Bordetella bronchiseptica (8). Recognition of the species $B$. pertussis is especially important in human medicine as it is the major causative agent of whooping cough, or pertussis (5). The severity of pertussis is usually much less with $B$. parapertussis infection. $B$. bronchiseptica has been isolated most frequently from the respiratory tracts of a variety of other mammals and may produce such respiratory diseases as bronchopneumonia (8) and infectious atrophic rhinitis (9).

In this investigation, we examined the deoxyribonucleotide sequence relationships among Bordetella species. We also considered the question of whether or not separation of the organisms on different host species might have promoted speciation. Preliminary observations on the deoxyribonucleic acid relatedness of Bordetella species have been reported previously (3; W. E. Kloos, W. J. Dobrogosz, J. W. Ezzell, and B. R. Kimbro, Abstr. Annu. Meet. Am. Soc. Microbiol. 1978, H122, p. 124).

\section{MATERIALS AND METHODS}

Bacterial strains. The 16 strains studied and their sources are listed in Table 1 . All of the Bordetella cultures were maintained on Bordet-Gengou agar slants (supplemented with $15 \%$ sheep blood) at $4^{\circ} \mathrm{C}$. Each of the strains obtained for this study conformed to its original species description $(3,8)$.

† Journal paper no. 6602 of the North Carolina Agricultural Research Service, Raleigh, NC 27650.
Cultivation and lysis of Bordetella species for DNA isolation. For the isolation of unlabeled deoxyribonucleic acid (DNA), B. pertussis strains were grown in a modified Stainer-Scholte broth medium containing $1 \%$ enzymatically hydrolyzed casein $(3,11)$. For the growth of cells to be used as inocula, the above-mentioned medium was supplemented with $1.5 \%$ agar (Difco Laboratories) and $1 \%$ activated charcoal (neutralized). B. parapertussis and B. bronchiseptica were grown in brain heart infusion broth (Difco Laboratories). Cells for lysis were produced as follows. Cells from a 24- to 36 -h-old agar slant culture were suspended in $1 \mathrm{ml}$ of saline $\left(\simeq 1 \times 10^{9}\right.$ to $5 \times 10^{9}$ colonyforming units) and were used to inoculate $500 \mathrm{ml}$ of the appropriate broth medium (above) contained in a 2-liter Erlenmeyer flask. The inoculated cultures were shaken at $250 \mathrm{rpm}$ at $34^{\circ} \mathrm{C}$. B. pertussis cultures were shaken for a period of 36 to $48 \mathrm{~h}$, and $B$. parapertussis and $B$. bronchiseptica cultures were shaken for 18 to $24 \mathrm{~h}$, until the cell density reached approximately 5 $\times 10^{8}$ to $5 \times 10^{9}$ colony-forming units per ml. Cultures were then centrifuged at $4^{\circ} \mathrm{C}$, and the cell pellet was suspended in 50 to $100 \mathrm{ml}$ of saline-ethylenediaminetetraacetate buffer $(0.1 \mathrm{M} \mathrm{NaCl}-0.05 \mathrm{M}$ ethylenediaminetetraacetic acid, $\mathrm{pH} 7.0$ ), containing $100 \mu \mathrm{g}$ of lysozyme per ml. Pronase B (Calbiochem) $(500 \mu \mathrm{g} / \mathrm{ml})$ may be substituted for lysozyme with equally satisfactory results. The cell suspension was frozen overnight at $-20^{\circ} \mathrm{C}$. After it was thawed, the cell suspension was incubated at $37^{\circ} \mathrm{C}$ until lysis was clearly evident (usually within $20 \mathrm{~min}$ ), at which time sodium lauryl sulfate was added to a final concentration of $2 \%$.

For the isolation of labeled DNA, all Bordetella strains were grown in $750 \mathrm{ml}$ of modified StainerScholte broth medium, containing a mixture of 11 amino acids instead of casein hydrolysate (3), a reduced level of $\mathrm{KH}_{2} \mathrm{PO}_{4}(15 \mathrm{mg} / 750 \mathrm{ml})$, and carrierfree $\left[{ }^{32} \mathrm{P}\right]$ orthophosphate $(10 \mathrm{mCi} / 750 \mathrm{ml})$, in a 2-liter Erlenmeyer flask. Cultures were shaken at $250 \mathrm{rpm}$ for 
TABLE 1. Strains used in this study

\begin{tabular}{|c|c|c|}
\hline Strain & Source & Obtained from ${ }^{a}$ \\
\hline $\begin{array}{l}\text { Bordetella pertussis } \\
\text { ATCC } 10380 \\
\text { ATCC } 12741 \\
\text { NCTC } 10902 \\
\text { Tohama L5 } \\
\text { BB-185 } \\
\text { BB-134 }\end{array}$ & $\begin{array}{l}\text { Human } \\
\text { Human } \\
\text { Human } \\
\text { Human } \\
\text { Human } \\
\text { Human }\end{array}$ & $\begin{array}{l}\text { ATCC } \\
\text { ATCC } \\
\text { NCTC } \\
\text { BB } \\
\text { BB } \\
\text { BB }\end{array}$ \\
\hline $\begin{array}{l}\text { Bordetella parapertussis } \\
\text { NCTC } 5952 \\
\text { ATCC } 15237 \\
\text { ATCC } 15989 \\
\text { ATCC } 21449\end{array}$ & $\begin{array}{l}\text { Human } \\
\text { Human } \\
\text { Human } \\
\text { Human }\end{array}$ & $\begin{array}{l}\text { NCTC } \\
\text { ATCC } \\
\text { ATCC } \\
\text { BB }\end{array}$ \\
\hline $\begin{array}{l}\text { Bordetella bronchiseptica } \\
\text { ATCC } 4617 \\
\text { ATCC } 19395 \\
\text { ATCC } 31124 \\
\text { K-1011 } \\
\text { K-1012 }\end{array}$ & $\begin{array}{l}\text { Unknown } \\
\text { Dog } \\
\text { Dog } \\
\text { Unknown } \\
\text { Guinea Pig }\end{array}$ & $\begin{array}{l}\text { ATCC } \\
\text { ATCC } \\
\text { R. A. Goodnow }{ }^{b} \\
\text { M. J. Pickett } \\
\text { M. J. Pickett }\end{array}$ \\
\hline $\begin{array}{l}\text { Rhizobium japonicum (DNA) } \\
\quad 61 \mathrm{~A} 76\end{array}$ & Soybean & G. H. Elkan ${ }^{d}$ \\
\hline
\end{tabular}

${ }^{a}$ ATCC, American Type Culture Collection, Rockville, Md.; NCTC, National Collection of Type Cultures, London, England; BB, Bureau of Biologics, Food and Drug Administration, Bethesda, Md.

${ }^{b}$ Burns-Biotec, Omaha, Neb.

' Department of Microbiology, University of California at Los Angeles, Los Angeles.

${ }^{d}$ Department of Microbiology, North Carolina State University, Raleigh N. C.

24 to $48 \mathrm{~h}$ at $34^{\circ} \mathrm{C}$. Cell lysis procedures were similar to those described above for unlabeled DNA.

Isolation of DNA. Bordetella species DNA was isolated according to a modification of the procedures of Brenner and co-workers (1; D. J. Brenner and A. G. Steigerwalt, personal communication) as reported by Kloos and Wolfshohl (4). DNA was fragmented by sonication with a Branson Sonifier cell disruptor (model 185) to a molecular size of about $0.5 \times 10^{5}$ to $1.0 \times 10^{5}$. Labeled DNA fragments were further purified by passing them through a hydroxyapatite column at $60^{\circ} \mathrm{C}$ in $0.14 \mathrm{M}$ phosphate buffer plus $0.4 \%$ sodium lauryl sulfate, after dissociation by heating at $100^{\circ} \mathrm{C}$ for $6 \mathrm{~min}$. Preparations with a relatively high zero binding time value $(>8 \%$ ) were passed through the hydroxyapatite column once more.

DNA reassociation reactions. A $0.1-\mu \mathrm{g}$ amount of sheared, heat-denatured, $\left[{ }^{32} \mathrm{P}\right] \mathrm{DNA}$ was allowed to react with $120 \mu \mathrm{g}$ of sheared, heat-denatured, unlabeled DNA in $1 \mathrm{ml}$ of $0.28 \mathrm{M}$ phosphate buffer for 20 $\mathrm{h}$ at either 65 or $80^{\circ} \mathrm{C}$ (optimal and stringent reassociation criteria, respectively). The actual binding of labeled DNA fragments to unlabeled DNA from the same source (homologous reactions) was $76 \pm 9 \%$. The concentration of labeled DNA was small enough to prevent significant reassociation of labeled DNA fragments with one another $(4 \pm 2 \%)$.

Separations of single- and double-stranded DNA. At the conclusion of reassociation reactions, double-stranded (hybridized) DNA was separated from unreacted, single-stranded DNA on hydroxyapatite by the batch procedure described by Brenner and co-workers (1). The percent relative binding was de- termined by dividing the fraction of labeled DNA bound to hydroxyapatite in heterologous reactions by that bound in the homologous reaction and multiplying the quotient by 100 .

\section{RESULTS AND DISCUSSION}

The results of reassociation reactions with $\left[{ }^{32} \mathrm{P}\right] D N A$ from reference and type strains of Bordetella species are shown in Table 2. As shown in the data, the DNA relatedness among these so-called species is so close that all strains tested could be considered as belonging to a single species, although a formal proposal to this effect will not be made at this time. There is a suggestion of a very slight divergence among DNAs from $B$. pertussis and the other species, but certainly not to the extent generally accepted for different genospecies. At the stringent criterion, the relative binding of $B$. pertussis DNA to $B$. parapertussis was $75 \pm 9 \%$, and to B. bronchiseptica DNA it was $73 \pm 8 \%$; on the other hand, intraspecies binding was $93 \pm 8 \%$. Under similar conditions the relative binding of $B$. parapertussis DNA to $B$. bronchiseptica DNA was $85 \pm 9 \%$. In earlier preliminary studies (3), we determined that the thermal stability of heterologous DNA duplexes formed by the reassociation of DNAs between a selected strain of each of the Bordetella species was very high 
TABLE 2. Reassociation reactions with $\left[{ }^{32} \mathrm{P}\right] \mathrm{DNA}$ from reference and type strains of Bordetella species

\begin{tabular}{|c|c|c|c|c|c|c|c|c|c|c|}
\hline \multirow{4}{*}{ Source of unlabeled DNA } & \multicolumn{10}{|c|}{$\%$ relative binding of labeled DNA from: } \\
\hline & \multicolumn{4}{|c|}{ B. pertussis } & \multicolumn{2}{|c|}{$\begin{array}{l}\text { B. parapertus- } \\
\text { sis NCTC } \\
5952^{\alpha}\end{array}$} & \multicolumn{4}{|c|}{ B. bronchiseptica } \\
\hline & \multicolumn{2}{|c|}{ ATCC 10380} & \multicolumn{2}{|c|}{ BB-185 } & \multirow{2}{*}{$65^{\circ} \mathrm{C}$} & \multirow{2}{*}{$80^{\circ} \mathrm{C}$} & \multicolumn{2}{|c|}{ ATCC $19395^{a}$} & \multicolumn{2}{|c|}{ ATCC 31124} \\
\hline & $65^{\circ} \mathrm{C}$ & $80^{\circ} \mathrm{C}$ & $65^{\circ} \mathrm{C}$ & $80^{\circ} \mathrm{C}$ & & & $65^{\circ} \mathrm{C}$ & $80^{\circ} \mathrm{C}$ & $65^{\circ} \mathrm{C}$ & $80^{\circ} \mathrm{C}$ \\
\hline \multicolumn{11}{|l|}{ B. pertussis } \\
\hline ATCC 10380 & $100^{b}$ & 100 & & & 71 & 80 & 61 & 72 & & \\
\hline ATCC 12741 & 98 & 92 & & & 74 & 76 & 62 & 67 & & \\
\hline BB-185 & 104 & 84 & 100 & 100 & 60 & 69 & 63 & 62 & 80 & 74 \\
\hline BB-134 & 82 & 101 & 88 & 78 & 87 & 66 & 66 & 60 & 87 & 71 \\
\hline NCTC 10902 & & & 92 & 78 & & & & & 77 & 71 \\
\hline Tohama L5 & & & 96 & 83 & & & & & 79 & 76 \\
\hline \multicolumn{11}{|l|}{ B. parapertussis } \\
\hline NCTC $5952^{a}$ & 78 & 68 & & & 100 & 100 & 78 & 78 & & \\
\hline ATCC 15237 & 81 & 74 & & & 103 & & 78 & 86 & & \\
\hline ATCC 15989 & 70 & 89 & 87 & 87 & 99 & 89 & 108 & 70 & 96 & 86 \\
\hline ATCC 21449 & 81 & 78 & 77 & 60 & 101 & 105 & 77 & 85 & 91 & 82 \\
\hline \multicolumn{11}{|l|}{ B. bronchiseptica } \\
\hline ATCC $19395^{a}$ & 87 & 84 & & & 94 & 94 & 100 & 100 & & \\
\hline ATCC 4617 & 80 & 73 & & & 88 & 99 & 85 & 92 & & \\
\hline K-1011 & 71 & 87 & 73 & 73 & 96 & 76 & 84 & 85 & 87 & 90 \\
\hline $\mathrm{K}-1012$ & 71 & 72 & 79 & 75 & 72 & 98 & 75 & 93 & 93 & 97 \\
\hline ATCC 31124 & 69 & & 85 & 85 & & & & & 100 & 100 \\
\hline \multicolumn{11}{|l|}{ Rhizobium japonicum } \\
\hline $61 \mathrm{~A} 76$ & 0 & 0 & 0 & 0 & 0 & 0 & $<1$ & $<1$ & 0 & 0 \\
\hline
\end{tabular}

${ }^{a}$ Type strain. ATCC 10380 was the proposed reference strain for $B$. pertussis at the time of this investigation. More recently, ATCC 9797 has been designated the type strain of B. pertussis (10) although additional study will be required to determine whether it is suitable for this purpose.

${ }^{b}$ Relative binding data represent the average of duplicate reassociation reactions.

$\left(\Delta T_{m(\mathrm{e})}=0.7\right.$ to 1.6$)$. These results support our present observations on the relative binding of DNAs between various Bordetella species.

Since there are still some practical reasons for making a distinction on phenotypic grounds (3, 8 ), the three groups might be best considered as separate subspecies. B. bronchiseptica strains usually grow more rapidly and produce larger colonies than the others, utilize citrate, reduce nitrates, demonstrate strong urease activity, possess the specific heat-labile antigen factor 12 , and are motile. The distinction between $B$. pertussis and $B$. parapertussis strains is not always clear, but usually $B$. parapertussis grows well on blood-free peptone agar and produces a browning of this medium (phase $4 \mathrm{~B}$. pertussis strains also grow well on this medium, but the characteristically more virulent phase 1 strains do not). B. parapertussis strains also usually grow more rapidly on Bordet-Gengou agar than do $B$. pertussis strains, utilize citrate, demonstrate moderate urease activity, and possess the specific heat-labile antigen factor 14.

In contrast to accumulating evidence that certain cutaneous staphylococci have evolved concurrently with their hosts $(2,4)$, the very close
DNA relatedness of Bordetella species isolated from distantly related hosts (e.g., humans, dogs, and guinea pigs) would suggest that the genome of these bacteria has not diverged much with changes in host range. Perhaps the major habitat (i.e., mucosal surfaces of the trachea and bronchi and associated ciliated epithelial cells) of Bordetella species $(6,7)$ has not changed much with the evolution of certain mammals. If selective niche properties have not changed significantly, divergence and ultimate speciation of the inhabiting bacteria might be severely limited. An alternative explanation may be that the spread of Bordetella species to certain hosts (e.g., from lower mammals to humans) may be relatively recent in biological time.

\section{ACKNOWLEDGMENTS}

The technical assistance of J. F. Wolfshohl, V. Morgan, and S. L. Benson is gratefully acknowledged.

This work was supported by research contract no. 223-761201 from the Bureau of Biologics, Food and Drug Administration.

\section{REPRINT REQUESTS}

Address reprint requests to: Dr. Wesley E. Kloos, Department of Genetics, North Carolina State University, Raleigh, NC 27650. 


\section{LITERATURE CITED}

1. Brenner, D. J., G. R. Fanning, A. Rake, and K. E Johnson. 1969. A batch procedure for thermal elution of DNA from hydroxyapatite. Anal. Biochem. 28:447459.

2. Kloos, W. E. 1980. Natural populations of the genus Staphylococcus. Annu. Rev. Microbiol. 34:559-592.

3. Kloos, W. E., W. J. Dobrogosz, J. W. Ezzell, B. R. Kimbro, and C. R. Manclark. 1978. DNA-DNA hybridization, plasmids, and genetic exchange in the genus Bordetella, p. 70-80. In C. R. Manclark and J. C. Hill (ed.), International Symposium on Pertussis, Department of Health, Education and Welfare publication no. (NIH) 79-1830. U.S. Government Printing Office, Washington, D.C.

4. Kloos, W. E., and J. F. Wolfshohl. 1979. Evidence for deoxyribonucleotide sequence divergence between staphylococci living on human and other primate skin. Curr. Microbiol. 3:167-172.

5. Linnemann, C. C. 1978. Host-parasite interactions in pertussis, p. 3-18. In C. R. Manclark and J. C. Hill (ed.), International Symposium on Pertussis, Department of Health, Education and Welfare publication no. (NIH) 79-1830. U.S. Government Printing Office, Washington, D.C.
6. Muse, K., D. Findley, L. Allen, and A. M. Collier. 1978. In vitro model of Bordetella pertussis infection: pathogenic and microbicidal interactions, p. 41-50. In C. R. Manclark and J. C. Hill (ed.), International Symposium on Pertussis, Department of Health, Education and Welfare publication no. (NIH) 79-1830. U.S. Government Printing Office, Washington, D.C.

7. Pittman, M. 1970. Bordetella pertussis-bacterial and host factors in the pathogenesis and prevention of whooping cough, p. 239-270. In S. Mudd (ed.), Infectious agents and host reactions. The W. B. Saunders Co., Philadelphia.

8. Pittman, M. 1974. Genus Bordetella Moreno-Lopez 1952, p. 282-283. In R. E. Buchanan and N. E. Gibbons (ed.), Bergey's manual of determinative bacteriology, 8th ed. The Williams \& Wilkins Co., Baltimore.

9. Ross, R. F., J. R. Duncan, and W. P. Switzer. 1963. Turbinate atrophy in swine produced by pure cultures of Bordetella bronchiseptica. Vet. Med. 58:566-570.

10. Skerman, V. B. D., McGowan, V., and Sneath, P. H. A. (ed.). 1980. Approved lists of bacterial names. Int. J. Syst. Bacteriol. 30:266.

11. Stainer, D. W., and M. J. Scholte. 1971. A simple chemically defined medium for the production of phase I Bordetella pertussis. J. Gen. Microbiol. 63:211-220. 